\title{
Water Security in a Changing Environment: Concept, Challenges and Solutions
}

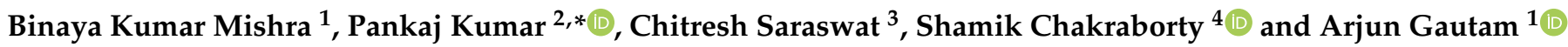 \\ 1 School of Engineering, Pokhara University, Pokhara 33700, Nepal; bkmishra@pu.edu.np (B.K.M.); \\ arjun.gautam@pu.edu.np (A.G.) \\ 2 Natural Resources and Ecosystem Services, Institute for Global Environmental Strategies, \\ Hayama 240-0115, Japan \\ 3 The Fenner School of Environment \& Society, Australian National University, Acton, Canberra 2601, \\ Australia; Chitresh.Saraswat@anu.edu.au \\ 4 Faculty of Sustainability Studies, Hosei University, Tokyo 1-2-8160, Japan; shamik.chakraborty.76@hosei.ac.jp \\ * Correspondence: kumar@iges.or.jp; Tel.: +81-046-855-3858 (ext. 3058)
}

Citation: Mishra, B.K.; Kumar, P.; Saraswat, C.; Chakraborty, S.; Gautam, A. Water Security in a Changing Environment: Concept, Challenges and Solutions. Water 2021, 13, 490. https://doi.org/10.3390/ w13040490

Academic Editor: Richard

C. Smardon

Received: 7 January 2021

Accepted: 9 February 2021

Published: 14 February 2021

Publisher's Note: MDPI stays neutral with regard to jurisdictional claims in published maps and institutional affiliations.

Copyright: (c) 2021 by the authors. Licensee MDPI, Basel, Switzerland. This article is an open access article distributed under the terms and conditions of the Creative Commons Attribution (CC BY) license (https:/ / creativecommons.org/licenses/by/ $4.0 /)$

\begin{abstract}
Water is of vital and critical importance to ecosystems and human societies. The effects of human activities on land and water are now large and extensive. These reflect physical changes to the environment. Global change such as urbanization, population growth, socioeconomic change, evolving energy needs, and climate change have put unprecedented pressure on water resources systems. It is argued that achieving water security throughout the world is the key to sustainable development. Studies on holistic view with persistently changing dimensions is in its infancy. This study focuses on narrative review work for giving a comprehensive insight on the concept of water security, its evolution with recent environmental changes (e.g., urbanization, socioeconomic, etc.) and various implications. Finally, it presents different sustainable solutions to achieve water security. Broadly, water security evolves from ensuring reliable access of enough safe water for every person (at an affordable price where market mechanisms are involved) to lead a healthy and productive life, including that of future generations. The constraints on water availability and water quality threaten secured access to water resources for different uses. Despite recent progress in developing new strategies, practices and technologies for water resource management, their dissemination and implementation has been limited. A comprehensive sustainable approach to address water security challenges requires connecting social, economic, and environmental systems at multiple scales. This paper captures the persistently changing dimensions and new paradigms of water security providing a holistic view including a wide range of sustainable solutions to address the water challenges.
\end{abstract}

Keywords: water security; water scarcity; climate change; IWRM; socioeconomic changes; sustainable development

\section{Introduction}

Water is the foundation of life and necessity for everyone. However, it is becoming an increasingly scarce and degraded natural resource for millions of the world's population. Adequate water, which is necessary for various uses for a rapidly growing population, is one of the major challenges in recent years. It is a critical issue as the increase in food production to meet the future population will have to be achieved with the same water resources. Growing populations and climate change are added burdens to the global water crisis. More than 1.1 billion people have inadequate access to clean drinking water globally, and approximately 2.6 billion people lack basic sanitation facilities [1,2]. Water stress is increasing rapidly especially in developing nations of the world. According to the United Nations [3], global water use over the last century has been growing at twice the rate of population increase. As a result, approximately 1.2 billion people live in areas of physical water scarcity, where supply of water is not enough to meet the demand [4]. Apart from 
physical scarcity, economic scarcity is another major issue for water insecurity. As of now, about 1.6 billion people face economic water scarcity, where people do not have enough financial means to access existing water sources. Lack of safe water access is gradually becoming a crisis for millions of people around the world that is responsible for poor health, destruction of livelihoods, and unnecessary suffering for the poor [5].

Water shortages are the most pressing challenge for socioeconomic and human development in general. Water shortages can lead to ecosystem degradation, worsening health and destruction of livelihood [6]. Increasing human pressure threatens the ability to provide adequate water resources and functioning of ecosystem services in the arid and semiarid regions and are particularly vulnerable to climate and land changes. As the human population grows and economic activity grows, water degradation has become a global concern [7]. Poor water quality, which makes water unfit for use, has multiple health and environmental consequences, and further reduces water availability. Contamination of the surface and groundwater is becoming one of the biggest threats to the available fresh water.

Today, more than half of the global population reside in urban areas [3]. With change in demography characterized by massive migration into cities, it is projected to further increase in percentage of urban population. Urban water supply systems for various applications as well as wastewater management for the increasing population is a serious threat, especially in developing countries. These cities have not been able to provide minimum water services to their growing population. Considering the urbanization pattern, it is urgent to improve water supply and wastewater treatment systems. These components should be seriously incorporated into urban planning.

A brief description of population and share of freshwater availability across different continents is shown in Figure 1 to highlight the issue of water scarcity.

Increase in water-related disasters is another important issue in the context of global change [8]. The number of deaths and economic damage caused by water-related disasters such as floods, droughts, landslides, and land subsidence has increased dramatically. Climate change and variability, land use changes, urbanization, migration patterns, energy problems, and food production caused by demographic change and economic development can exacerbate more uncertain risks.

Flooding is one of the most damaging natural disasters in the world. Floods are often seen as a natural phenomenon due to extreme weather events. However, in practice, human activity changes the environment in multiple ways, changes the water cycle, and hence more flooding. Therefore, flood risk and flood risk management are closely related to human activities. The impact of land-use change includes not only urbanization, but also the development and consolidation of agriculture [9]. Land-use policy has been a key factor in permitting urban developments in areas of risk. Flood risk results from extreme events, changes in the natural environment, and poor disaster management institutions which have the ability to reduce and manage risks.

Similarly, drought has multiple physical and social aspects. Lack of precipitation alters water resources and agriculture systems, and the impact can be severe, depending on the resilience of local communities and populations. Tensions between competing water use further worsen due to conflict between human use and environmental flow requirements [10]. Drought can constrain the multiple societal uses of water, including energy production, at local and regional levels. Many people rely on groundwater for drinking water, food security, and sustainable living. Groundwater use has increased significantly over the past 50 years due to its better quality and easy availability even during droughts [11]. 


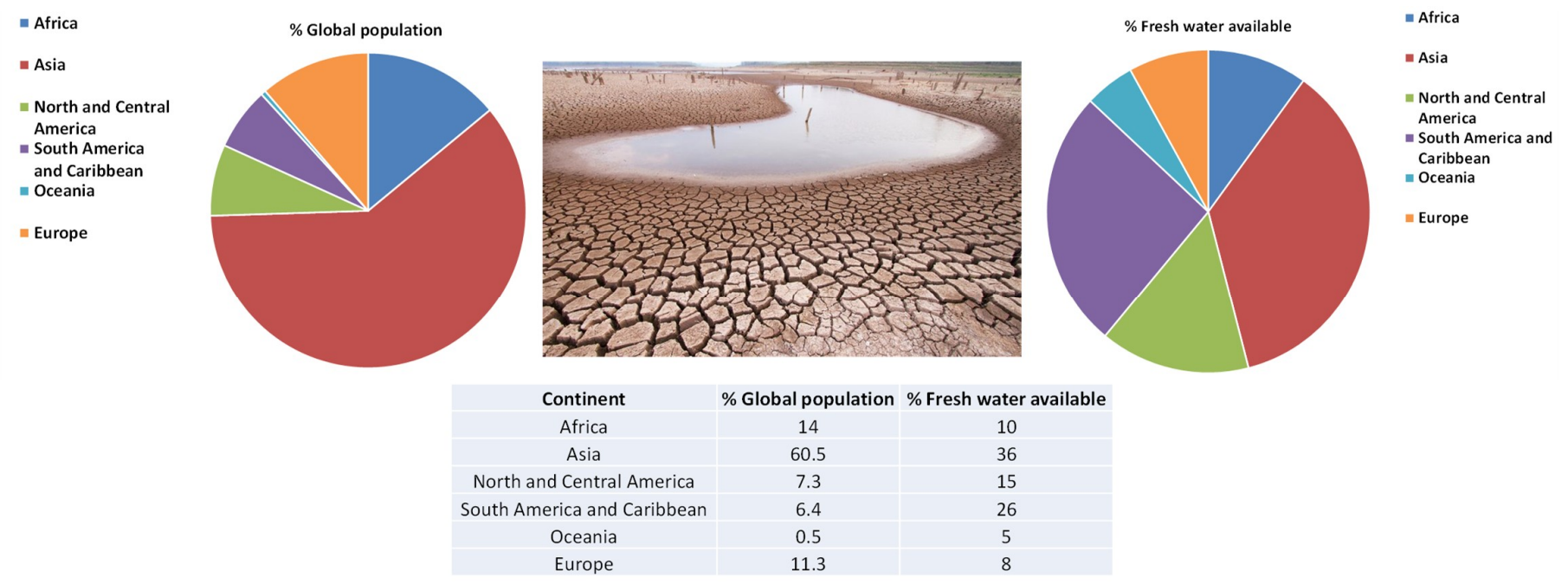

Figure 1. A brief description of population distribution and water availability around the world $[1,3,8,12,13]$.

These challenges require further research, implementation of new science-based methodologies, and endorsement of principles of integrated water resources management which can sustainably address various water-related issues. It is important to understand and manage water quantity and quality worldwide, and especially in the developing world. Overcoming the water crisis remains one of the most critical challenges our generation is facing [12] and developing clean potable water, managing wastewater efficiently and providing basic sanitation facilities for sustainability and human progress [13,14]. The United Nations (UN) Sustainable Development Goals 2030 will not be possible without achieving a water secure world first.

While resource allocation and competition requirements are to represent the first set of water security challenges, the second major focus for water security is on extreme events. It is very important to design a wide range of sustainable solutions, which addresses various water problems. With increased concerns on the sustainable use of limited water resources, in recent years, policy makers, organizations, funding agencies, and individuals largely use the 'water security' term to express their opinions for solving various water-related problems. However, there is no consensus on framing of water security concepts for solving water problems in a sustainable manner. Water security employing different disciplines is proposed as a starting point for solving various water related problems.

In the past few years, constructive efforts have been made to improve water security issues. Water security includes the sustainable use and protection of water systems, protection against water-related hazards, sustainable development of water resources, and protection of water functions and services for humans and the environment [15].

There is a need for holistic approaches to address the water security challenges and inclusion of the social, economic, and environmental dimensions at multiple scales. The holistic approaches can act as a catalyst for progress in many sectors such as public health, energy security, climate resilience, poverty reduction, and accelerate the pace of achieving the Sustainable Development Goals (SDGs). Water security is important to understand and manage various challenges in the context of environmental change. The interface between communities of researchers, practitioners, and stakeholders is seen as increasingly important for the recognition and management of water security.

Lack of infrastructure and capacity development; weak and rigid governance systems, and lack of interdisciplinary approach are among the major reasons for the increase in solving various water-related problems. Framing the challenges of water security goes beyond single-issue indicators such as water stress. In a rapidly changing world, we are solving new problems with old solutions. The status quo is no longer enough, and conventional models will not be able to achieve water security issues. It is crucial to 
shift from ad hoc and isolated water solutions to integrated water resources management approaches, which yield more sustainable and resilient systems. A new paradigm is therefore needed that considers alternative solutions for achieving water security. The paper highlights water security issues and sustainable solutions at different scales and presents good practices to address water security challenges. This paper aims to review various water related problems and challenges in the global change context, explore emerging paradigms of water security assessment, and finally seek sustainable solutions towards achieving water security.

Therefore, this paper is aimed to address key questions on water security as: (i) what is water security? (ii) What are various dimensions of water security? (iii) How can we assess water security? and (iv) What are different sustainable solutions to improve water security? Answers to these questions will be of great value to policy-makers, who are responsible for making well-informed decisions and investment in the field water management.

\section{Methodology}

For this study we carried out a narrative literature review. To carry out the literature review, we searched through keywords water security, water scarcity, climate change, integrated water resource management, and sustainable development to focus our study within the review questions (see Section 1). The Claivariate Analytics's Web of Science (WoS) was used to search for scientific literature and articles pertaining to the combination of keywords mentioned above from year 2000 to 2020 . Web of Science was chosen as it is one of the world's largest scientific citation search platforms, has an extensive coverage of a wide spectrum of studies related to a topic of interest, and a frequent source for literature review based analysis [16]. A variety of articles were searched to ensure that the majority of the relevant articles and the arguments they capture have been identified. After completing the search, abstracts were read and articles that were common (duplicates) in the searched databases were discarded. All the remaining abstracts were then read to find an answer to our review questions. We did not include all the articles of the abstracts we reviewed because of the relevancy of the arguments in the abstract and articles they represent. We then read all the articles thoroughly, this included a total of 71 articles, which show a diverse line of arguments on the review question. We then synthesized the findings from this literature review into a narrative and integrated into two main types of streams of argument-problems and solutions of water security under changing environmental and socioeconomic context. A list of reviewed papers used to identify different dimensions for water security is shown in Appendix A. The whole study is described in the flowchart shown in Figure 2.

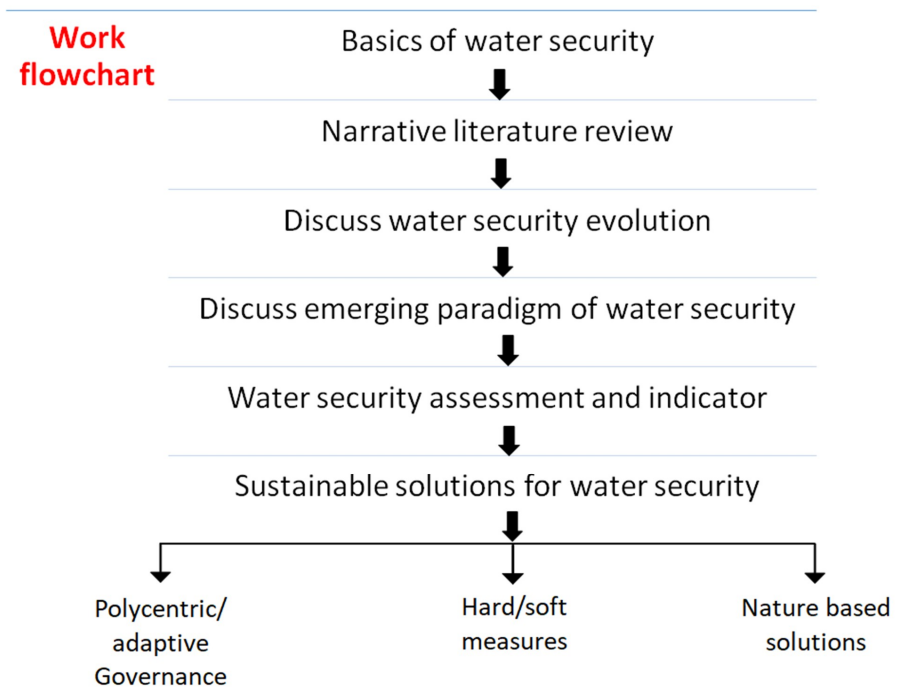

Figure 2. Flow chart explaining the work done in this study. 


\section{Water Security: Concept and Evolution}

Water security is critical to achieving sustainable and comprehensive growth. A watersecure world uses the productive power of water and reduces its destructive impacts. It is a world where everyone has safe, affordable, clean water to live a healthy and productive life. It is a world where communities are protected from floods, droughts, landslides, erosion, and water-borne diseases. Water security promotes environmental protection and social justice and deals with the consequences of poor water management. In general, several definitions have been proposed for water security, reflecting the desire to manage water resources. The 'UN agency on Water' defines the water security as "the capacity of a population to safeguard sustainable access to adequate quantities of water with acceptable quality necessary for sustaining livelihoods, human well-being, socio-economic development, ensuring protection against water- related disasters, and for preserving ecosystems in a climate of peace and political stability" [13]. Increasing water security lies in: (i) ensuring the availability of adequate and reliable water resources of acceptable quality to provide water services for all social and economic activity in a manner that is environmentally sustainable; (ii) mitigating water-related risks such as floods, droughts, and pollution; (iii) addressing the conflicts that may arise from disputes over shared waters, especially in situations of growing stress, and turning them into win-win solutions. Water security is emerging as a possible unified concept for water managers. Operationalizing the concept of water security means identifying its various aspects, setting goals, and exploring actions to achieve these goals.

In recent years, the focus of water security has become more diverse, expanding from water scarcity to clean water, ecosystem services and overall human wellbeing [17]. Conventional approaches focused on a single aspect and narrow perspective such as development studies tend to focus on national scales only, economists' main concerns are about the economic aspect of the problem, hydrologists often only focus on watershed scales, and the social scientists focused on research work around community only [17]. The new dimensions pledged to attain water security in a sustainable way with long-term vision, which proposes a range of sustainable solutions based on economic, environmental, and societal aspects [18].

The spatial and temporal considerations are important determinants for water security. Rijsberman [19] explained the supply problem when water is truly scarce in the physical sense, and demand problem when enough water is available but not used in a better or sustainable way. Hydrological extreme conditions such as floods and droughts can occur at the same location within the same year. Therefore, use of average available water cannot represent a measure of water scarcity or excess. In the monsoon season, many regions of Asia suffer from water scarcity while the average annual water resource availability appears to be abundant. Large countries like India can have water scarcity and flooding at the same time, but in different parts of the country. The situation of uneven distribution of water resources is going to be aggravated due to climate change. The understanding of water scarcity is vital as it affects the views on the most effective policies to deal with water crisis. The Intergovernmental Panel on Climate Change (IPCC) reports indicated that more than $87 \%$ of the climate change impact will be on water related infrastructure and increasing negative impacts of global warming is likely to increase the variations, frequency, and severity of weather such as extreme droughts and floods occurring [20]. On the global scale, a current water withdrawal is well below renewable water resources limit, but the concern is the high unpredictability of water resources in coming years [21]. Virtual water trade can be one of the effective options to address water scarcity, which is estimated around $1000 \mathrm{~km}^{3}$ /year internationally although only a very small part of virtual water trade is utilized to compensate for water shortages. Another major challenge is pollution and deterioration of surface and ground water bodies in rapidly growing cities and elsewhere in the developing world. Understanding of causes and measures that lead to improvement of water quality degradation is limited. In order to address water quality degradation, several soft and hard measures need to be formulated at individual, 
community, and institution level. It needs balance between technical and social approaches. Water quality is another major variable and its analysis is beneficial for security of the environment, human use, and understanding the water stress. Historical evolution of water security technologies is important to understand the present and future concept of water security (Figure 3). Urban regions required new strategies to cope with the transitioning phases of water requirements with the development of urban areas. Water supply for demand management was a concept in the water supply system in cities, which evolved and moved in the direction of water sensitive cities due to various factors. Various drivers are responsible for this transitioning phase of water such as rapid population growth and consumption patterns that use more water. To solve the emerging problem of water security, it is important to change the management response that appears in response to social and political factors [22].

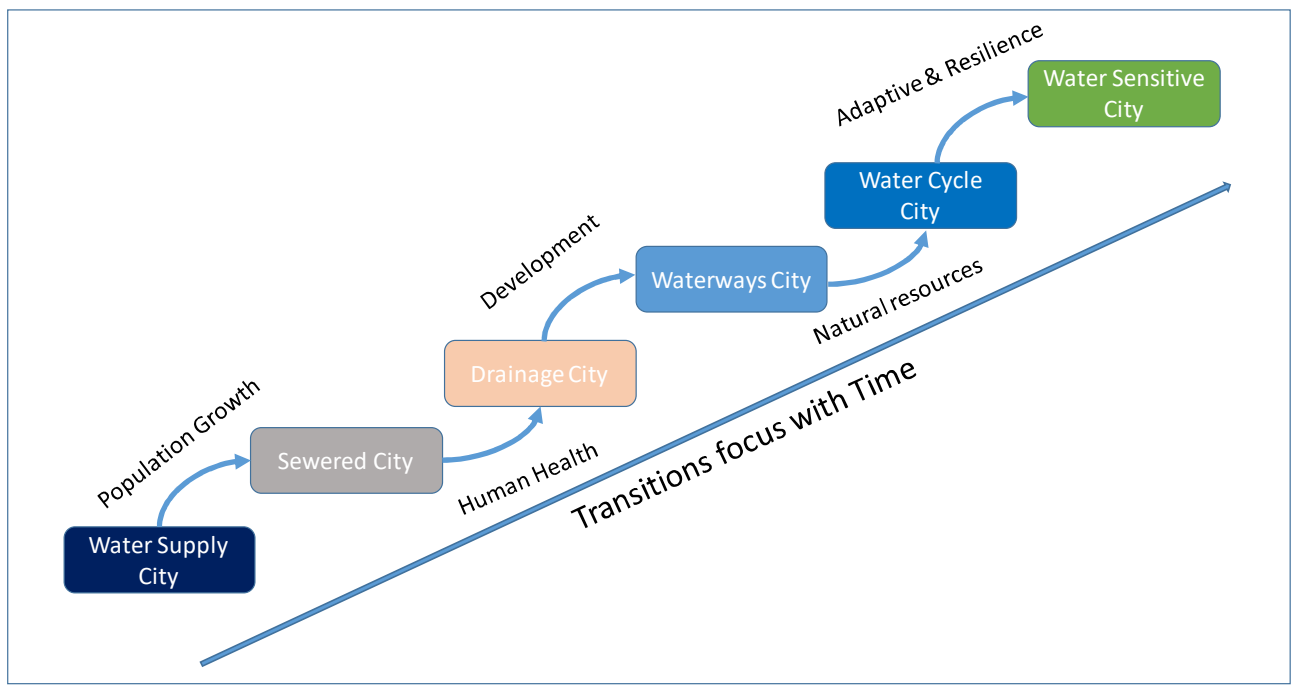

Figure 3. Changing paradigms of Water Security and Transition Phase for cities (adapted from brown et al. 2008 [22]).

\section{Emerging Paradigms of Water Security}

Water Security embodies a complex, multidimensional and interdependent set of issues. With increasing pressures on water resources, there is heightened competition for the water uses at local, regional, and international scales, both between diverse sectors of the economy and jurisdictions. This comprises basic societal needs such as drinking water supply, irrigation, hydropower, and industrial uses. Achieving water security is also dependent on the water quality, which is a further key dimension of water use. Rivers are used to receive, transport, and dilute wastes, and intensification of human activities is putting increasing pressure on the quality of both surface waters and groundwater, with consequences for water resource availability for various uses. Water-related ecosystem functions, with their dependence on water quantity (and its temporal variability) and water quality is another critical dimension of water security.

Securing water for people and the environment is a necessary condition for sustainable growth, ending poverty and hunger, and achieving the SDGs. The dominant threats to water availability, quality, and supply vary geographically and over time. This entails achieving water security is not a dynamic goal, which evolves with changing dynamics. It is a dynamic process affected by changing climate, political set up, economic growth, and resource degradation. Moreover, as social, cultural, political, economic priorities, and values change, the goal for achieving water security evolves with them. In this background, the study argued for evaluating water security challenges under emerging paradigms and seeking the solutions. 
Paradigm is a concept of envisioning the future of societal interaction with the environment based on the shared assumptions and values [23]. The emerging paradigms are significant in the context of continuous shifts in societal interaction with natural resources such as water. In order to bring holistic solutions to water security, the nature and characteristics of paradigm changes are necessary. Historically, paradigm shifts are seen as a continuous and necessary part of policy making. The important question that arises here is why there is a need to rethink water security under emerging or new paradigms. Societal interactions and values around water are continuously changing. For example, the shift from Millennium Development Goals (MDGs) to the SDGs, the focus of the water security concept has shifted from only water supply and demand in cities towards the perception of water as an economic resource shared between countries. The paradigm shift in water emphasizes on how societies are valuing water as a resource and support this transition. This shift comprises water governance, which is the capacity of governments to manage water equitably and efficiently, including across borders [24]. Due to increased economic development and climate change the uncertainty is increased which impacted the interactions of society with water resources. In the traditional paradigms, the water crisis is generally considered as technology related problems but under emerging paradigms focus is shifted towards recycle and reuse of water, considering waste and stormwater as resources, managing demand effectively, promoting green infrastructure, increasing community and stakeholder participation, effective governance, and multidisciplinary approach to achieve water security.

The four different paradigms shifts are identified in this paper to evaluate the water security and seek the solutions to achieve the goal. In changing context and challenges, the new approaches to govern the water is suggested by Huitema et al. [25], are the adaptive water governance and polycentric approaches to govern. Another perspective of Integrated water resource management (IWRM) is popular among the developing nations, how the IWRM evolves in current perspective. The nature-based solutions perspective is gaining popularity worldwide to achieve water security and still many scholars focus on the combination of hard/soft approaches to achieve water security (see Section 5). The paradigm shift in the water sector constitutes how water is managed in the current context under different challenges and transitioning the way of managing water towards diversifying water resources and building resilient infrastructure. Shift in financing the water sector is significant in emerging paradigms where engaging the private sector partnerships and reducing the nonrevenue water is in focus. Collaboration at different scales through regional and national cooperation and agreements are helpful in shifting towards system thinking approaches. This study envisioned the challenges and solutions to achieve water security under emerging paradigms in a changing environment.

\section{Water Security Assessment and Indicators}

Water security captures the complex concept of overall water management with resource conservation and its use [26]. Water security should be represented by indicators to promote its quantification. There are different kinds of water scarcity indicators proposed by various studies and explained in literature such as water stress indicator or Falkenmark indicator, water resources vulnerability index, economic water scarcity index, and water poverty index, among many others. There are several advantages of translating water security into numerical terms to encourage clarity and establish a common understanding of a concept around which there currently exists substantial ambiguity. This helps to facilitate discussion on the presence or absence of water security, or the scale and threshold for evaluating the degree of water security. This also assesses the extent to which water security on the ground has been achieved in various locations.

The treatment of wastewater is a very important aspect of water security. Historically, wastewater was considered as waste only, although it could be a valuable resource. If treated properly, wastewater can be reused and contribute to lesser pollution in water bodies. The recycling of water is the concept of reusing the treated wastewater or stormwater 
for many useful purposes, such as irrigation, toilet flushing, needs of industries, and in some aspect for ground water recharge $[27,28]$. Recycled water or water reuse offers many kinds of resources and financial savings [29] and if this can be tailored to meet the quality standard required for the water use, then the recycled water can be considered as a vital resource because it offers series of benefits such as useful for irrigation, cooling water for power plants and refineries, toilet flushing at household level, controlling the dust in the city, mixing and preparing cement during construction activities, beautification of artificial lakes and parks, and industrial processes. This provides us with ample reason to consider treatment of water as a sustainable solution for achieving water security.

Sources of uncertainty in water security assessment can be demonstrated by riskbased water security indicators, such as the uncertainty in the climate model outputs. The IPCC report indicated that climate change is increasing the frequency of extreme weather conditions like flood, drought, etc. More than $87 \%$ of the climate change impact will be on water related infrastructure [20]. These indicators are important in analysis of risks based on what if scenarios, which provides the essential evidence to enable options between alternative courses of action. The risk analysis explores the range of likely future situations ranging from business as usual to extremely unlikely conditions [30]. Decision making process involves choices between different courses of actions counting their benefits in terms of risk reduction or cost-benefit ratio.

Scale is critical in assessing water security [31]. National level assessments make it difficult to take action at operationalization level. Agriculture dominates water use in the Asia-Pacific region, but focuses on water productivity, which is often used as a means of improving production. Therefore, this indicator deals with the available water, and how to use, for example, an increase in water storage, can become a more urgent issue in areas with economic water shortages. There is also a question mark over use of such indicators that explains the overall picture of the country, especially if watersheds cross national borders. Watershed based water security can be defined as "sustainable access on a watershed basis to adequate quantities of water of acceptable quality to ensure human and ecosystem health" [26].

It is possible that the region can be concluded water secure or insecure but interestingly, without the explicit environmental consideration the shared conclusion from water indicator's analysis that water security is achieved by the developed part of the world such as many countries in Europe, North America, Australia, and Japan, is a kind of flaw [19]. Creating and using indicators for water security has to be directed towards some management control or assessment action. Originally, a single indicator was mainly used to assess the quality of rivers for human use. Earlier, for example, a simple parameter indicator (e.g., Biochemical oxygen demand (BOD)) was sufficient as a river pollution control measure. As the industrial revolution began, various types of chemicals started spilling into rivers requiring multiple measurements. Thus, indicators were required to measure multiple effects and combine them into single-value indicators. A recent shift to water security has called for the addition of economic and ecosystem concerns. In addition, the largest consumer of water in most countries is irrigation agriculture. With the rapid growth of the global population, the fear of a decline in the supply of water available in food production, industry, and homes has become a major problem. This has led to a search for indicators of water resource security.

Water security clearly requires an integrated approach while recognizing and accepting that tradeoffs may be needed between the different water-using sectors. Indicators tend to be heuristic, and political and water specialists need to focus on those indicators which tell the most compelling story to other sectors if they are to encourage water-smart investments. Roger Calow [26] suggested five pillars of water security where indicators are water availability and access, risk and variability, equity and livelihoods, ecosystems and biodiversity, and institutions and actors [26]. Ian Makin [26] focused on national and regional measures of water security, rather than individual basins highlighting the importance of water management issues in 49 countries across the Asia and Pacific region 
and the threat from many sources-population growth, urbanization, increasing water pollution, over-abstraction of groundwater, water-related disasters, and climate change.

Asian Water Development Outlook (AWDO) [1] provides a robust, pragmatic, and readily understood framework for assessing water security. This report presents a framework for the assessment of water security in five key dimensions: household water security, economic water security, urban water security, environmental water security, and resilience to water-related disasters. Status of water security in five dimensions represents inherent tension among water uses that emerge under increasing stress from competing water use sectors. These, when aggregated, provide an indicator of national and regional water security. The indicators (referred as dimensions) are seen as the means of measuring the outcomes of integrated water resources management. These provide a baseline for analyzing trends and the effects of policies and reforms that can be monitored and reported to stakeholders and offer a new way for leaders to look at the strengths and weaknesses of water resources management and service delivery. These indicators also indicate the direction and priority for increasing investment, improving governance, and expanding capacity in the water sector. Dunn and Bakker [32] developed a water security framework as a tool for improving governance for watersheds in Canada. This is in contrast to others who seek to develop national or regional indicators describing the challenge of developing and applying indicators at the watershed level that were originally designed for national or regional application and question their relevance and sensitivity for use at a community level and for including socioeconomic considerations. However, considering the importance of water quality and transboundary water resource management, this study explained water security based on seven dimensions that are shown in Figure 4.

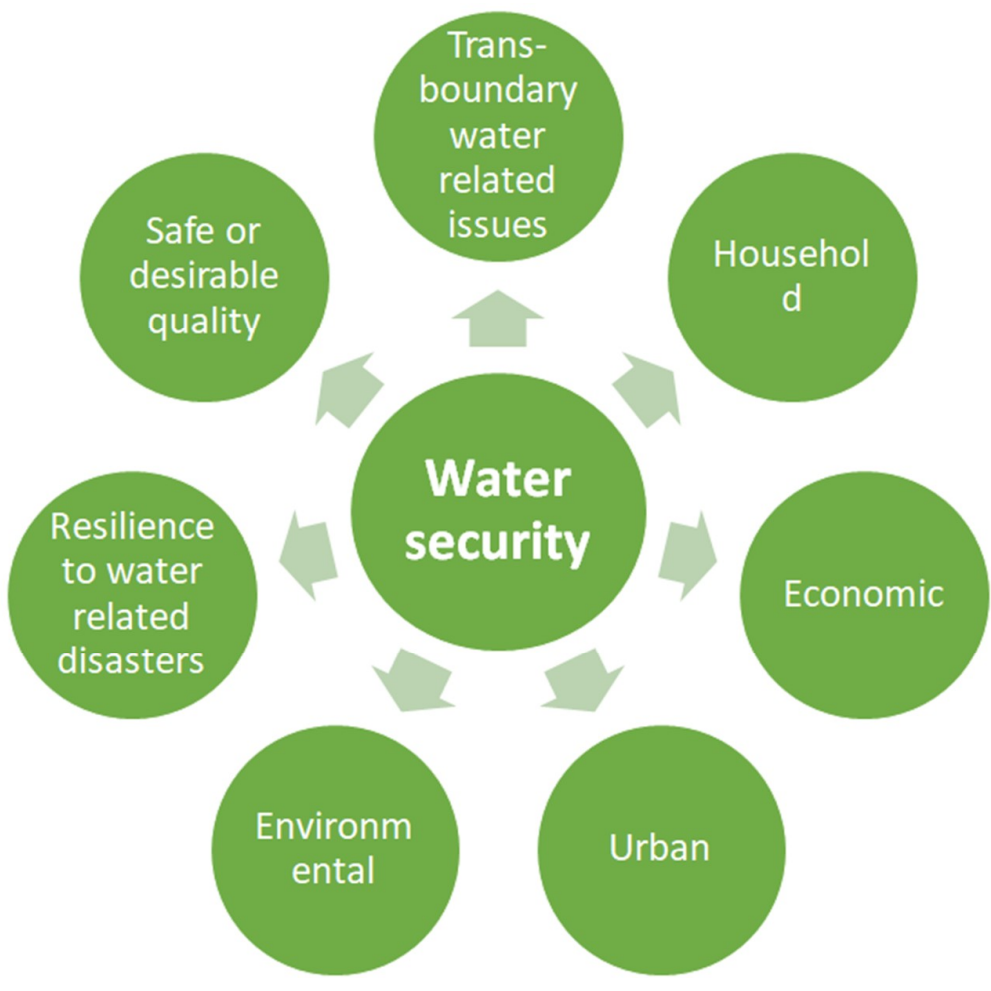

Figure 4. Water security dimensions (based on the Appendix A).

\section{Sustainable Solutions}

Given global changes and its potential impacts water security is a growing concern. It touches upon all aspects of life and requires a holistic approach, which actively integrates social, cultural, and economic perspectives, scientific and technical solutions, and attention to societal dynamics. The complexities in water security point out that there will be different solutions for managing water scarcity at different spaces and times. To address 
water security, interdisciplinary collaborations are required across sectors, communities, and political borders to manage the competition or conflicts over water resources. Here, sustainable water management is a key which focuses on the conjunctive and efficient use of different water resources and on water allocation strategies that build the economic and social returns and enhance the water productivity. In addition, there is a need for a special focus on equity in access to water as well and social impacts of water allocation policies.

Based on the complex and intricate nature of water security, its dimension and different paradigms as mentioned above, this section advocates various sustainable solutions to achieve water security under three themes. A summary for reviewed papers supporting ideas for these three different themes of solutions to achieve water security is shown in Table 1.

Table 1. List of reviewed papers used to find water security solutions under following three different themes.

\begin{tabular}{cc}
\hline Water Security Solution & References \\
\hline $\begin{array}{c}\text { Governance (Adaptive and Polycentric) } \\
\text { including Integrated Water Resource }\end{array}$ & Kumar et al., 2020; Pahl Wostl et al., 2018; \\
Management (IWRM) & Saraswat et al., 2017; Head et al., 2014; Cook \\
and Bakker, 2012; Wiek and Larson, 2012; & Uhlendahl et al., 2011; Huitema et al., 2009; \\
Brown et al., 2008; Masago et al., 2019; & Al-Jawad et al., 2019; Weather et al., 2009; \\
Radiff 1999 \\
\hline Combination of Hard and Soft Approaches & Masago et al., 2019; Mo et al., 2019; Mishra \\
& et al., 2018; Tian et al., 2017; Voulvoulis et al., \\
& 2015; Grafton et al., 2011; Biswas and Tortajada, \\
& 2019; Brown et al., 2008; Mishra et al., 2020 \\
\hline Nature-Based Solutions & Van-Rees et al., 2019; Lindsay et al., 2019; \\
& Vorosmarty et al., 2018; Jamero et al., 2017; \\
& Chakraborty and Chakraborty 2017; \\
& Gunderson et al., 1995; Mishra et al. 2020 \\
\hline
\end{tabular}

\subsection{Polycentric and Adaptive Governance}

Water governance becomes a sustainable solution when it safeguards ecosystems yet is able to consider social and economic wellbeing of people [33]. Governance refers not only to national level water legislation, regulations and institutions, but also the processes to promote stakeholder or community participation in designing water and sanitation systems and empowering communities with knowledge by increasing their ability to make decisions about the management systems. Restructuring of water governance methods refer to the social mobilization and actions designed in promotion of ownership, capacity building, coinvestment, willingness to pay for services, and incentives for participation at the community level. Van Rijswick et al. [34] recognized several factors important for sustainable water governance. These are knowledge on water systems, monitoring and enforcement, values, principles, and policy discourses, responsibility, authority and means, stakeholder involvement, conflict resolution capability, tradeoffs between social objectives such as allocation, regulation and agreements, and financial arrangements. These can be taken as a roadmap for sustainable water governance. Besides, the water governance solutions also promote gender equality in decision making [35]. It determines the relevant roles for the government entities to ensure the delivery of water and sanitation and keep checks on public and private players to meet the required needs. Building sustainable governance as solutions towards water security is a process, which is very effective in correcting market distortions, incentives, and adjustments to affordable pricing.

The water sector is considered underperforming and requires massive investment in infrastructure building and developing capacity. The complexity of the decision-making system, inability to receive timely information, conflicts of water rights (vertical and 
horizontal integration), poor coordination and interactions, and lack of holistic planning are the reasons and important challenges of water governance [36].

To deal with this complexity and scale of governance challenge for water security, here we would especially like to focus on polycentric governance. Polycentric means that water management plans and policies should be framed and agreed by all relevant stakeholders. In other words, both top-down and bottom-up approaches should be given weight. For adaptive governance, more emphasis will be on finding the best pathways to make robust water management plans amid rapid global changes. The benefit of such plans should reach the end users in terms of providing clean water, protection from hydrological hazards, and maintaining the health of the ecosystem.

In order to make a region more sustainable in terms of water resources, its locally available water resources must not be compromised by its socioeconomic activities. There is an urgent need for co-management, which includes the cycle of co-design, co-implementation, and co-delivery throughout the whole water cycle.

(a) Regional Circular and Ecological Sphere (RCES)—RCES is a concept that complements and supports regional resources by building broader networks, which is composed of natural connections (connections among forests; city and countryside; groundwater, rivers and the sea) and, economic connections (composed of human resources, funds, and others), thus complementing each other and generating synergy [37]. In terms of water security, this concept will lead to self-reliant and decentralized society. This will promote water reuse, reclamation, and restoration using decentralized water management systems. Additionally, it will enhance our reliability on renewable source of energy with less dependence on water resources.

(b) Participatory Watershed Land-use Management (PWLM) approach-PWLM is another very innovative and successful approach for more robust water resource management [38]. It helps to make land-use and climate change adaptation policies more effective at a local scale. This is an integrative method using both participating tactics and computer simulation modeling for the water resource management at a regional scale. The whole process is divided into four main steps: (a) scenario analysis, (b) impact assessment, (c) developing adaptation and mitigation measures and its integration in local government policies, and (d) improvement of land-use plan.

(c) Citizen science-Citizen science can be generally defined as "the engagement of nonprofessionals in scientific investigations" $[39,40]$. This is also a unique way for the general people to contribute to monitor water pollution and its management progress. This can be done by participating in "citizen science" initiatives, e.g., by reporting detections of water pollution in their locality. Normally, the citizens involved here are volunteers and unpaid, and contribute out of their own personal interest in the topic of the investigation. Although this is an old technique, it got into the limelight recently because of advances in information and communications technology (ICT) including mobile smartphones with internet, GPS, and camera capabilities [40,41]. Use of ICT has made it much easier for citizen volunteers to interact with professional scientists and pass this useful information about water quality to the decision makers.

(d) Integrated Water Resource Management (IWRM) -IWRM is a vital approach to improve water security and sustainability through better water use efficiency and conservation. Although the term or the concept IWRM, is available and frequently being used by different stakeholders since the last few decades but its ground application remains questionable [42-45]. While much progress has been made on water quality, water quantity components, this study suggests the critical elements for the success of IWRM in the ground are to prioritize the inclusion of human or socioeconomic dimension, nexus dimension (water-food-energy-health) etc., which are still unexplored in most of the regions [46,47]. In general, conventional models helps us to quantify and project plausible future of the water environment, but they cannot guarantee their goal attainment because of adaptive responses by humans and management decisions which might have unintended consequences [48-50]. Therefore, 
an integrated perspective in analyzing water related risk through socio-hydrological pathways is deemed essential for better understanding the action research and policy implication for sustainable water management [46].

\subsection{Combination of Hard and Soft Measures}

(a) Water reuse, restoration and reclamation-Considering the interwoven issue of water scarcity in the lieu of rapid global change and frequent extreme weather conditions, it is important to think holistically for both water quality and quantity. This issue becomes more acute in case of countries with arid or semiarid environments with very little freshwater available. Henceforth, the concept of 3Rs (reduction, restoration, and reclamation) is very important to achieve a water secure world. Water reuse in terms of restoration and reclamation become a matter of prime concern, which has multidimensional (financial, socioeconomic, and environmental) benefits. To achieve this, all water users and stakeholders must be aware about the use of reclaimed water, its social acceptance, and pros and cons of using this reclaimed water [51]. However, in order to make this reuse more sustainable, a sound and scientific knowledge about the source of wastewater or treated saltwater, chemical composition, and its sectoral usage is most important [52]. For reducing the water usage, several innovative ways are already in practice such as smart monitoring to minimize nonrevenue loss of water, intelligent irrigation using agriculture engineering in the field, rainwater harvesting, financing urban water usage, water tariff, etc. [53].

(b) Water conservation technologies (WCT) - WCT are of larger importance for developing countries like India with traditional irrigation schemes having efficiencies of $30-40 \%$ [54]. It is envisioned that increased use of WCT will play an important role in improving the productivity of rain-based agriculture and irrigation efficiency. Water conservation and water saving technologies are delivering benefits such as improved water productivity, improved farm profits and others, if it is well planned and managed. In addition, the WCT reduces the nonbeneficial consumptive water use such as the well-managed drip irrigation or orchard crops and enhances the distributional profits under regulatory frameworks.

(c) Modeling and Forecasting-Different hydrologic simulation models are powerful tools, which enable to assess various implications of the rapidly changing global processes on water resources variables. Although, various hydrologic models with specific features are available for simulating the water resources variables like runoff, groundwater recharge, surface water-groundwater interaction, water quality, contaminant fate, and transport etc. Based on the goals to be achieved, different models (continuous or event-based type; empirical, conceptual, and physical types) can be selected. However, these models can be effectively applied only when it has a significant amount of required input datasets and skilled people to handle it. For data scarce countries, it is important to have easy access to free available data and tools for sustainable water management. On the other hand, capacity building is also critically important for making these countries self-sufficient for doing better in analyzing future status of water resources and hence can design appropriate adaptation and mitigation strategies for water resource management.

\subsection{Nature-Based Solutions}

Nature-based solutions are those that use or simulate natural processes to address contemporary challenges, including those associated with water management. Its objectives are, for instance, to increase water availability (soil water retention and groundwater recharge are nature-based solutions), to improve water quality (natural and artificial wetlands, and riparian forest buffers), or to reduce water-related disasters and climate change risks (restoration, flood plains, and roof gardens). In other words, nature-based solutions are ecological processes driven by vegetation and soil in forests, pastures, humid areas, as well as in agricultural and urban landscapes, which play an important role in water 
movement, storage, and transformation. Nature-based solutions offer some of the most effective and sustainable ways to improve water security, and they frequently offer additional benefits for communities where they are implemented, including improved agriculture, job creation, and climate resilience. It can also play an important role in improving the supply and quality of water and reducing the impact of natural disasters.

Freshwater supply depends on healthy functioning of freshwater (riverine) ecosystems. However, studies are scarce that consider whole ecosystems such as a river [55]. Furthermore, most of the riverine systems are heavily altered anthropogenically, this is a big challenge that makes sustainable water resource management, miss vital 'pieces' or functions that relate to the diversity of the ecosystem that are needed to bring solutions that are sustainable. Freshwater ecosystems are often highly engineered and thus can undergo this act of missing the vital pieces of ecosystem diversity that is quite common, which eventually make the freshwater systems lose their resilience.

For example, freshwater systems such as rivers have undergone disconnection in the longitudinal, lateral, and vertical dimensions of the river systems [56], disrupting (and distorting) the freshwater ecosystems such as a river that continues to deliver freshwater related ecosystem benefits $[56,57]$.

The degradation in resilience does not exclude the society that lives within the freshwater ecosystems (e.g., a river basin) causing decision-making gridlocks. For example, distorted governance on freshwater issues have occurred due to human interventions such as dams and barrages, changing of the river courses, covering the flow (and in many cases surrounding landscapes) with impervious surfaces have compromised diverse ecosystem functions and resilience in freshwater environments through decades of mismanagement. These gridlocks especially take place when high economic returns are available at the expense of functional diversity [58]. Therefore, keeping the freshwater ecosystems as diverse as possible can enhance this resilience, which can be used as a thread or anchor to bind the whole ecosystem together. Using the resilience concept as a binder can make the freshwater system undergo changes without changing its vital state and function. A key sustainable solution in this regard is binding through the available knowledge component in the freshwater landscape through stakeholder engagement that creates values in diverse ecosystem functions for capturing the dynamism and nonlinearity of the freshwater ecosystems (including its connection to other ecosystems) [59-62]. It is here that nature-based solutions (or landscape-based solutions) can work as eco-friendly technologies to enhance development of freshwater services, characterized by a number of low-cost, more flexible adaptation options in contrast to conventional 'grey' technologies, which the developing world, especially in urban areas, are now trying to implement [63].

Additionally, sustainable water management can be achieved by facilitation of a change in mindset towards landscape-based water management such as participatory watershed land use management (PWLM). The participatory approach can identify and engage champions within its offices and communities to promote long-term sustainable planning for urban water security [64-66]. It can be challenging at times due to low interest among citizens [67]. Pace of urbanization is important while introducing sustainable construction practices. Watershed management plans should be based on retrofitting models in collaboration with stakeholders and communities are essential. This should be based on physical analysis of existing water scarcity coping practices. Interactive design records are needed to adopt smart water management.

Another set of sustainable solutions include interlinked water, energy, and food components, with a balance between natural resource use and society's demand on such resources $[67,68]$. This forms a critical nexus essential for addressing challenges of sustainable development. Water, food, and energy are dependent on each other and share many comparable characteristics, including people's livelihoods, so a collective (i.e., a nexus) approach should be able to address this interdependency effectively.

The relationship between ecosystem and water security is mutually beneficial and a core component of sustainable solutions to water security as this ensures that sufficient 
and good quality of freshwater is available to support the functioning of ecosystem (and healthy functioning of the ecosystem continues to deliver good quality and quantity of water). Unfortunately, understanding of the relationship between ecosystem and water security is still a new territory but stressed as an important component to achieve overall development in the society such as Sustainable Development Goals [69,70]. As ecosystems provide water required both in terms of quality and quantity for different communities, maintaining food security as well as to mitigate hydrological hazards necessary to achieve water security at a watershed level, it is important to ensure that ecosystems are conserved.

Traditional and local adaptation strategies for an ecosystem-based approach are needed as they are often based on 'time tested' methods and adaptation strategies for water management in the whole landscape, and not only its physical and chemical parameters as modern scientific methods try to achieve. Further investigation on local adaptation strategies is also needed for achieving water security and fighting effectively against the climate change impacts is necessary for policy makers [71]. For example, every village, town, or other type of human settlement unit can have a list of traditional and local adaptation strategies so that they can deliver at the time of acute water crisis. It is reported that the water and social agreement for a water sensitive city would be significantly different to that conventional urban water approaches and integrates the normative values of environmental protection, demand-supply security, flood control, human wellbeing, and economic sustainability [22].

Nature-based solutions are now fast becoming the center stage of solving diverse and complex problems related to water security. In 2018 for the first time, Brazil hosted the world launching of the United Nations World Water Development Report, which publicly stated the importance of nature-based solutions (NBS) for water. According to Stefan Uhlenbrook, the Coordinator and Director of the UN World Water Assessment Programme (WWAP), reservoirs, irrigation canals, and water treatment plants are not the only water management instruments at our disposal. "We can't wait for nature to solve all problems by itself, but we can get inspired and use it in favor of the planet."

\section{Conclusions}

Flooding, drought, inadequate access to drinking water, and sanitation are some of the well-known water problems across the globe. There is a need for sustainable solutions, which are appropriate for varying contexts, local consideration to societal values, which leverage the multiple uses and make use of synergies with management of other resources. As these problems are increasing across different regions and different scales, there is an urgency to take measures for the protection of the water and to improve legislation and public awareness in this field to find the optimum way to manage, protect, and serve our limited water resources, and enforce water pollution control and the protection of water by suggesting remediation alternatives to reduce or control the influence of the contamination.

This paper explored new paradigms and evolving definitions of water security, and presented a wide range of sustainable solutions to solve various water-related problems. Water security is fundamental to achieving any kind of sustainable economic and human development. The challenges of water security are unprecedented, and a new approach to provide the underpinning science for water security management is urgently needed by the global community. An integrative framing of water security should take place at the policy and governance level, where established priorities and decisions are taken with agreement of stakeholders. An integrative approach is likely to bring good water governance and set a new approach to sustainable water management. The evolving paradigm of achieving water security will be able to provide sufficient water for socioeconomic activities for domestic, industrial, and commercial purposes, and clean drinking water to meet basic needs at an affordable price with proper sanitation, while treating and collecting wastewater to curb water pollution. Various dimensions of achieving water security extend to protecting ecosystems and increasing the role of nature to sustain its own functioning and developing 
ability to cope with changing conditions. It also deals with timely response to the risk of water related disasters such as droughts, floods, spreading of diseases, and pollution.

Attaining water security in a changing context is not a simple or 'one size fits all' solution. Expanding the portfolio of solutions from fully engineered systems to management systems based on capacity building, community awareness, managing the wetlands, and conservation of aquifers need to incorporate the natural processes to achieve desired results to attain a water secure future for human wellbeing. It addresses the impacts of human activities on water quantity and quality, aquatic ecosystems and climate, and the context of rapid economic growth and climate change. It can be concluded that water security has multiple and highly interconnected dimensions, and that each of these involves complex interactions between human society and the natural environment. In conclusion, achieving a water secure world requires balance between social, environmental, and economic components. It requires adequate integration of soft and hard measures such as in storing and transporting water and in protecting the resource itself.

Author Contributions: Conceptualization: B.K.M., P.K., C.S., S.C., A.G.; methodology: B.K.M., C.S., P.K., S.C.; formal analysis: B.K.M., P.K., C.S., S.C.; investigation: B.K.M., P.K., C.S., S.C.; writingoriginal draft preparation: B.K.M., P.K., C.S., S.C.; writing-review and editing: B.K.M., P.K., C.S., S.C., A.G. All authors have read and agreed to the published version of the manuscript.

Funding: This research received no external funding.

Institutional Review Board Statement: Not applicable.

Informed Consent Statement: Not applicable.

Conflicts of Interest: The authors declare no conflict of interest.

\section{Appendix A}

Table A1. List of reviewed papers and their relation with seven different dimensions of water security.

\begin{tabular}{|c|c|c|}
\hline $\begin{array}{l}\text { Reference } \\
\text { Number }\end{array}$ & Title of the Reviewed Papers & $\begin{array}{c}\text { Category (Key Topics According to the Seven } \\
\text { Dimensions of Water Security) }\end{array}$ \\
\hline [1] & Strengthening water security in Asia and the Pacific & Transboundary issues \\
\hline [2] & Water: Asia's new battleground & Transboundary issues, \\
\hline [3] & $\begin{array}{c}\text { Coping with water scarcity. Challenge of the twenty-first } \\
\text { century }\end{array}$ & Household, Economic, Urban, Environmental \\
\hline [4] & $\begin{array}{l}\text { Impact of urbanization on water shortage in face of climatic } \\
\text { aberrations }\end{array}$ & $\begin{array}{l}\text { Urban, Environmental, Transboundary issues, Safe } \\
\text { or desirable quality, Economic }\end{array}$ \\
\hline [5] & $\begin{array}{l}\text { Global water crisis and future food security in an era of } \\
\text { climate change }\end{array}$ & Economic, Environmental \\
\hline [6] & Water Crisis Report & $\begin{array}{c}\text { Transboundary issues, Economic, Environmental, } \\
\text { Safe or desirable quality, Resilience to water } \\
\text { related disasters }\end{array}$ \\
\hline [7] & Water quality management: a globally neglected issue & Safe and desirable quality \\
\hline [8] & Future Outlook of Urban Water Environment in Asian Cities & Economic, Urban, Environmental \\
\hline [9] & Land use, water management and future flood risk & $\begin{array}{l}\text { Resilience to water related disasters, Safe or } \\
\text { desirable quality }\end{array}$ \\
\hline [10] & $\begin{array}{l}\text { Determinants of residential water consumption: Evidence } \\
\text { and analysis from a 10-country household survey }\end{array}$ & Economic, Household \\
\hline [11] & $\begin{array}{l}\text { Responding to the challenges of water security: the Eighth } \\
\text { Phase of the International Hydrological Programme }\end{array}$ & $\begin{array}{c}\text { Resilience to water related disasters, } \\
\text { Environmental, Safe or desirable quality, } \\
\text { Household, Economic }\end{array}$ \\
\hline
\end{tabular}


Table A1. Cont.

\begin{tabular}{|c|c|c|}
\hline $\begin{array}{c}\text { Reference } \\
\text { Number }\end{array}$ & Title of the Reviewed Papers & $\begin{array}{l}\text { Category (Key Topics According to the Seven } \\
\text { Dimensions of Water Security) }\end{array}$ \\
\hline [12] & $\begin{array}{l}\text { Climate Change 2014: Synthesis Report. Contribution of } \\
\text { Working Groups I, II and III to the Fifth Assessment Report } \\
\text { of the Intergovernmental Panel on Climate Change }\end{array}$ & Environmental \\
\hline [13] & $\begin{array}{l}\text { UN-Water Analytical brief: Water security and the global } \\
\text { water agenda }\end{array}$ & $\begin{array}{l}\text { Environmental, Economic, Safe or desirable } \\
\text { quality, Resilience to water related disasters }\end{array}$ \\
\hline [14] & $\begin{array}{l}\text { A clash of paradigms in the water sector? Tensions and } \\
\text { synergies between integrated water resources management } \\
\text { and the human rights-based approach to development }\end{array}$ & $\begin{array}{l}\text { Environmental, Economic, Transboundary water } \\
\text { related issues, Safe or desirable quality }\end{array}$ \\
\hline [15] & Water security: what does it mean, what may it imply? & $\begin{array}{l}\text { Environmental Economic, Urban, Resilience to } \\
\text { water related disasters }\end{array}$ \\
\hline [16] & $\begin{array}{l}\text { Web of Science use in published research and review paper } \\
\text { Sciences 1997-2017: a selective, dynamic, cross-domain, } \\
\text { content-based analysis }\end{array}$ & For method used in this paper \\
\hline [17] & Water security: Debating an emerging paradigm & Integrative of the seven dimensions \\
\hline [18] & $\begin{array}{l}\text { China's water security: Current status, emerging challenges } \\
\text { and future prospects. Environmental Science and Policy }\end{array}$ & $\begin{array}{l}\text { Environmental, Economic, Urban, Safe or desirable } \\
\text { quality }\end{array}$ \\
\hline [19] & "Water scarcity: Fact or Fiction?" & Economic, Household, Urban, Environmental \\
\hline [20] & Climate, climate change and human health in Asian Cities. & Environmental, Urban, Safe or desirable quality \\
\hline [21] & Global hydrological cycles and world water resources & Environmental \\
\hline [22] & $\begin{array}{l}\text { Transitioning to Water Sensitive Cities: Historical, Current } \\
\text { and Future Transition States }\end{array}$ & Urban \\
\hline
\end{tabular}

[23] A comprehensive optimum integrated water resource management approach for multidisciplinary water resources management problems

[24] Governing water: contentious transnational politics and global institution building

Adaptive water governance: assessing the institutional

[25] prescriptions of adaptive (co-) management from a governance perspective and defining a research agenda

[26] Assessing Water Security with Appropriate Indicators

[27] Integrated urban water management scenario modeling for [27] sustainable water governance in Kathmandu Valley, Nepal

[28] Hydrogeochemical Evolution and Appraisal of Groundwater Quality in Panna District, Central India

Framework to assess sources controlling soil salinity

[29] resulting from irrigation using recycled water: an
application of Bayesian Belief Network

[29] resulting from irrigation using recycled wate
application of Bayesian Belief Network

Risk-based principles for defining and managing water

[30] security risk-based principles for defining and managing water security

[31] Urban water security indicators: Development and pilot.

[32] Fresh Water-Related Indicators in Canada: An Inventory and Analysis

Integrative of seven dimensions

Environmental, Transboundary water related issues

Household, Economic, Urban, Environmental,

Resilience to water related disasters, Safe or desirable quality, Transboundary issues Integrative of seven dimensions

Urban, Economic, Environmental,

Safe or desirable quality, Economic, Environmental

Safe or desirable quality, Urban, Households

Environmental, Economic, Safe or desirable quality, Resilience to waters related hazards

\begin{tabular}{|c|c|}
\hline [31] & Urban water security indicators: Development and pilot. \\
\hline [32] & $\begin{array}{c}\text { Fresh Water-Related Indicators in Canada: An Inventory } \\
\text { and Analysis }\end{array}$ \\
\hline [33] & $\begin{array}{l}\text { Water, people, and sustainability-a systems framework for } \\
\text { analyzing and assessing water governance regimes }\end{array}$ \\
\hline [34] & $\begin{array}{l}\text { Ten building blocks for sustainable water governance: an } \\
\text { integrated method to assess the governance of water }\end{array}$ \\
\hline
\end{tabular}


Table A1. Cont.

\begin{tabular}{|c|c|c|}
\hline $\begin{array}{l}\text { Reference } \\
\text { Number }\end{array}$ & Title of the Reviewed Papers & $\begin{array}{c}\text { Category (Key Topics According to the Seven } \\
\text { Dimensions of Water Security) }\end{array}$ \\
\hline [35] & $\begin{array}{l}\text { Climate justice in lieu of climate change: a sustainable } \\
\text { approach to respond to the climate change injustice and an } \\
\text { awakening of the environmental movement }\end{array}$ & Environmental \\
\hline [36] & $\begin{array}{c}\text { Population growth and water supply: The future of } \\
\text { Ghanaian cities. Megacities and Rapid Urbanization: } \\
\text { Breakthroughs in Research and Practice }\end{array}$ & Urban \\
\hline [37] & $\begin{array}{l}\text { Creation of a Regional Circular and Ecological Sphere } \\
\text { (RCES) to address local challenges }\end{array}$ & Environmental \\
\hline [38] & $\begin{array}{l}\text { Participatory approach for enhancing robust water resource } \\
\text { management: case study of Santa Rosa sub-watershed near } \\
\text { Laguna Lake }\end{array}$ & Urban, Environmental, Safe or desirable quality \\
\hline [39] & The history of public participation in ecological research & Environmental \\
\hline [40] & $\begin{array}{l}\text { Citizen science websites/apps for invasive species sightings: } \\
\text { An analysis of } 26 \text { ongoing initiatives. }\end{array}$ & Environmental \\
\hline [41] & Citizens as sensors: The world of volunteered geography & Environmental \\
\hline [42] & $\begin{array}{c}\text { IWRM: what should we teach? A report on curriculum } \\
\text { development at the University of the Western Cape, South } \\
\text { Africa }\end{array}$ & $\begin{array}{l}\text { Household, Economic, Urban, Environmental, } \\
\text { Resilience to water related disasters, Safe or } \\
\text { desirable quality, Transboundary issues }\end{array}$ \\
\hline [43] & $\begin{array}{l}\text { Integrated water resource management (IWRM): an } \\
\text { approach to face the challenges of the next century and to } \\
\text { avert future crises }\end{array}$ & $\begin{array}{l}\text { Household, Economic, Urban, Environmental, } \\
\text { Resilience to water related disasters, Safe or } \\
\text { desirable quality, Transboundary issues }\end{array}$ \\
\hline [44] & $\begin{array}{l}\text { Good water governance and IWRM in Zambia: challenges } \\
\text { and chances }\end{array}$ & $\begin{array}{l}\text { Household, Economic, Urban, Environmental, } \\
\text { Resilience to water related disasters, Safe or } \\
\text { desirable quality, Transboundary issues }\end{array}$ \\
\hline [45] & $\begin{array}{l}\text { The water-energy-food nexus: trade-offs, thresholds and } \\
\text { transdisciplinary approaches to sustainable development }\end{array}$ & $\begin{array}{l}\text { Economic, Urban, Environmental, Resilience to } \\
\text { water related disasters, Safe or desirable quality }\end{array}$ \\
\hline [46] & $\begin{array}{l}\text { Debates-Perspectives on socio-hydrology: Capturing } \\
\text { feedbacks between physical and social processes }\end{array}$ & Resilience to water related disasters \\
\hline [47] & $\begin{array}{l}\text { Stochastic multi-objective modelling for optimization of } \\
\text { water-food-energy nexus of irrigated agriculture }\end{array}$ & Economic, Environmental \\
\hline [48] & $\begin{array}{l}\text { Socio-hydrology: use-inspired water sustainability science } \\
\text { for the Anthropocene }\end{array}$ & $\begin{array}{l}\text { Environmental, Resilience to water related } \\
\text { disasters }\end{array}$ \\
\hline [49] & Earth systems: Model human adaptation to climate change & Economic, Urban, Environmental \\
\hline [50] & $\begin{array}{l}\text { Small-island communities in the Philippines prefer local } \\
\text { measures to relocation in response to sea-level rise }\end{array}$ & Household, Resilience to water related disaster \\
\hline [51] & $\begin{array}{l}\text { Solutions to water resource scarcity: water reclamation and } \\
\text { reuse }\end{array}$ & Economic, Urban, Environmental \\
\hline [52] & $\begin{array}{l}\text { Occurrence and risk assessment of emerging contaminants } \\
\text { in a water reclamation and ecological reuse project }\end{array}$ & Environmental, Safe or desirable water quality \\
\hline [53] & $\begin{array}{l}\text { The potential of water reuse as a management option for } \\
\text { water security under the ecosystem services approach }\end{array}$ & $\begin{array}{c}\text { Economic, Environmental, Safe or desirable water } \\
\text { quality }\end{array}$ \\
\hline [54] & $\begin{array}{l}\text { Post-adaptation behaviour of farmers towards soil and } \\
\text { water conservation technologies of watershed management } \\
\text { in India }\end{array}$ & Economic, Environmental \\
\hline [55] & $\begin{array}{l}\text { How is ecosystem health defined and measured? A critical } \\
\text { review of freshwater and estuarine studies }\end{array}$ & Economic, Environmental \\
\hline [56] & Rivers as Socioecological Landscapes & Environmental dimension \\
\hline [57] & Connectivity in rivers & Environmental dimension \\
\hline
\end{tabular}


Table A1. Cont.

\begin{tabular}{|c|c|c|}
\hline $\begin{array}{l}\text { Reference } \\
\text { Number }\end{array}$ & Title of the Reviewed Papers & $\begin{array}{c}\text { Category (Key Topics According to the Seven } \\
\text { Dimensions of Water Security) }\end{array}$ \\
\hline$[58]$ & $\begin{array}{l}\text { Barriers and Bridges to Renewal of Ecosystems and } \\
\text { Institutions }\end{array}$ & Environmental and Transboundary dimension \\
\hline$[59]$ & $\begin{array}{c}\text { Ecological stakeholder analogs as intermediaries between } \\
\text { freshwater biodiversity conservation and sustainable water } \\
\text { management }\end{array}$ & Environmental and Transboundary dimension \\
\hline$[60]$ & $\begin{array}{c}\text { Integrating the social, hydrological and ecological } \\
\text { dimensions of freshwater health: the Freshwater Health } \\
\text { Index }\end{array}$ & $\begin{array}{l}\text { Environmental, Safe or desirable quality, and } \\
\text { Resilience to water related disasters dimension }\end{array}$ \\
\hline$[61]$ & $\begin{array}{c}\text { Exploring spatial variations in the relationships between } \\
\text { residents' recreation demand and associated factors: a case } \\
\text { study in Texas }\end{array}$ & $\begin{array}{l}\text { Household, Economic, Urban, Environmental, } \\
\text { Resilience to water related disasters, Safe or } \\
\text { desirable quality dimension }\end{array}$ \\
\hline$[62]$ & Resilience and thresholds in river ecosystems & $\begin{array}{l}\text { Environmental, Resilience to water related } \\
\text { disasters dimension }\end{array}$ \\
\hline$[63]$ & $\begin{array}{c}\text { Managing urban water crises: adaptive policy responses to } \\
\text { drought and flood in Southeast Queensland, Australia }\end{array}$ & $\begin{array}{l}\text { Household, Economic, Urban, Environmental, } \\
\text { Resilience to water related disasters, Safe or } \\
\text { desirable quality dimension }\end{array}$ \\
\hline$[64]$ & $\begin{array}{c}\text { Participatory watershed land-use management approach: } \\
\text { Interfacing science, policy and participation for effective } \\
\text { decision making }\end{array}$ & $\begin{array}{l}\text { Environmental, Safe or desirable quality, and } \\
\text { Resilience to water related disasters dimension }\end{array}$ \\
\hline$[65]$ & $\begin{array}{c}\text { The Role of Community Champions in Long-Term } \\
\text { Sustainable Urban Water Planning }\end{array}$ & $\begin{array}{l}\text { Household, Economic, Urban, Environmental, } \\
\text { Resilience to water related disasters, Safe or } \\
\text { desirable quality dimension }\end{array}$ \\
\hline$[66]$ & $\begin{array}{l}\text { Public Participation in Natural Hazard Mitigation Policy } \\
\text { Formation: Challenges for Comprehensive Planning }\end{array}$ & $\begin{array}{c}\text { Household, Economic, Environmental, Resilience } \\
\text { to water related disasters, Safe or desirable quality } \\
\text { dimension }\end{array}$ \\
\hline$[67]$ & $\begin{array}{l}\text { Sustainable development and the water-energy-food nexus: } \\
\text { A perspective on livelihoods }\end{array}$ & $\begin{array}{l}\text { Household, Economic, Urban, Environmental, } \\
\text { Resilience to water related disasters, Safe or } \\
\text { desirable quality, Transboundary dimension }\end{array}$ \\
\hline$[68]$ & $\begin{array}{c}\text { Considering the energy, water and food nexus: towards an } \\
\text { integrated modelling approach }\end{array}$ & $\begin{array}{l}\text { Household, Economic, Urban, Environmental, } \\
\text { Resilience to water related disasters, Safe or } \\
\text { desirable quality, Transboundary dimension }\end{array}$ \\
\hline$[69]$ & $\begin{array}{l}\text { Ecosystem-based water security and the sustainable } \\
\text { development goals. }\end{array}$ & $\begin{array}{l}\text { Environmental, Resilience to water related } \\
\text { disasters, Safe or desirable quality dimension }\end{array}$ \\
\hline$[70]$ & $\begin{array}{l}\text { UN - United Nations. Sustainable Development Goal } 6 \\
\text { Synthesis Report } 2018 \text { on Water and Sanitation }\end{array}$ & $\begin{array}{l}\text { Household, Economic, Urban, Environmental, } \\
\text { Resilience to water related disasters, Safe or } \\
\text { desirable quality, Transboundary dimension }\end{array}$ \\
\hline$[71]$ & Global analysis of urban surface water supply vulnerability & $\begin{array}{l}\text { Household, Economic, Urban, Environmental, } \\
\text { Resilience to water related disasters, Safe or } \\
\text { desirable quality, Transboundary dimension }\end{array}$ \\
\hline
\end{tabular}

\section{References}

1. Asian Water Development Outlook (AWDO). Strengthening Water Security in Asia and the Pacific. 2016. Available online: https:/ / www.adb.org/publications/asian-water-development-outlook-2016 (accessed on 27 August 2018).

2. Chellaney, B. Water: Asia's New Battleground; Georgetown University Press: Washington, DC, USA, 2011.

3. UN-Water. Coping with Water Scarcity. Challenge of the Twenty-First Century; UN-Water; FAO: Geneva, Switzerland, $2007 ;$ p. 23.

4. Majumder, M. Impact of Urbanization on Water Shortage in Face of Climatic Aberrations; Springer Briefs in Water Science and Technology; Springer: Singapore, 2015; p. 98. ISSN 2194-7244.

5. Hanjra, M.A.; Qureshi, M.E. Global water crisis and future food security in an era of climate change. Food Policy 2010, 35, 365-377. [CrossRef]

6. Guppy, L.; Anderson, K. Water Crisis Report; United Nations University Institute for Water, Environment and Health: Hamilton, ON, Canada, 2017. 
7. Biswas, A.K.; Tortajada, C. Water quality management: A globally neglected issue. Int. J. Water Resour. Dev. $2019,35,913-916$. [CrossRef]

8. Masago, Y.; Mishra, B.K.; Jalilov, S.; Kefi, M.; Kumar, P.; Dilley, M.; Fukushi, K. Future Outlook of Urban Water Environment in Asian Cities; United Nations University: Tokyo, Japan, 2019.

9. Wheater, H.; Evans, E. Land use, water management and future flood risk. Land Use Policy 2009, 26, S251-S264. [CrossRef]

10. Grafton, R.Q.; Ward, M.B.; To, H.; Kompas, T. Determinants of residential water consumption: Evidence and analysis from a 10-country household survey. Water Resour. Res. 2011, 47, W08537. [CrossRef]

11. Jimenez-Cisneros, B. Responding to the challenges of water security: The Eighth Phase of the International Hydrological Programme, 2014-2021. Proc. IAHS 2015, 366, 10-19. [CrossRef]

12. IPCC. Climate Change 2014: Synthesis Report. Contribution of Working Groups I, II and III to the Fifth Assessment Report of the Intergovernmental Panel on Climate Change; Pachauri, R.K., Meyer, L.A., Eds.; IPCC: Geneva, Switzerland, $2014 ;$ p. 151.

13. United Nations University (UNU). UN-Water Analytical Brief: Water Security and the Global Water Agenda. Hamilton, ON, Canada. 2013, p. 47. Available online: http://inweh.unu.edu/wp-content/uploads/2013/11/water-security-and-the-globalwater-agenda (accessed on 16 August 2018).

14. Tremblay, H. A clash of paradigms in the water sector? Tensions and synergies between integrated water resources management and the human rights-based approach to development. (1 August 2010). Nat. Resour. J. 2011, 51, 307-356.

15. Schultz, B.; Uhlenbrook, S. Water security: What does it mean, what may it imply? In Proceedings of the International Symposium "Water for a Changing World Developing Local Knowledge and Capacity", Delft, The Netherlands, 13-15 June 2007.

16. Li, K.; Rollins, J.; Yan, E. Web of Science use in published research and review papers 1997-2017: A selective, dynamic, crossdomain, content-based analysis. Scientometrics 2018, 115, 1-20. [CrossRef]

17. Cook, C.; Bakker, K. Water security: Debating an emerging paradigm. Glob. Environ. Chang. 2012, 22, 94-102. [CrossRef]

18. Jiang, Y. China's water security: Current status, emerging challenges and future prospects. Environ. Sci. Policy 2015, 54, 106-125. [CrossRef]

19. Rijsberman, F.R. Water scarcity: Fact or Fiction? Agric. Water Manag. 2006, 80, 5-22. [CrossRef]

20. Kovats, S.; Akhtar, R. Climate, climate change and human health in Asian Cities. Environ. Urban. 2008, 20, 165-175. [CrossRef]

21. Oki, T.; Kanae, S. Global hydrological cycles and world water resources. Science 2006, 313, 1068-1072. [CrossRef]

22. Brown, R.; Keath, N.; Wong, T. Transitioning to Water Sensitive Cities: Historical, Current and Future Transition State. In Proceedings of the 11th International Conference on Urban Drainage, Edinburgh, UK, 31 August-5 September 2008.

23. Al-Jawad, J.Y.; Alsaffar, H.M.; Bertram, D.; Kalin, R.M. A comprehensive optimum integrated water resource management approach for multidisciplinary water resources management problems. J. Environ. Manag. 2019, 239, 211-224. [CrossRef]

24. Gareau, B.J.; Crow, B. Ken Conca. Governing Water: Contentious Transnational Politics and Global Institution Building; International Environmental Agreements; MIT Press: Cambridge, MA, USA, 2006; p. 466.

25. Huitema, D.; Mostert, E.; Egas, W.; Moellenkamp, S.; Pahl-Wostl, C.; Yalcin, R. Adaptive water governance: Assessing the institutional prescriptions of adaptive (co-) management from a governance perspective and defining a research agenda. Ecol. Soc. 2009, 14, 26. [CrossRef]

26. GWP. Assessing Water Security with Appropriate Indicators; Global Water Partnership: Stockholm, Sweden, 2014.

27. Saraswat, C.; Mishra, B.K.; Kumar, P. Integrated urban water management scenario modeling for sustainable water governance in Kathmandu Valley, Nepal. Sustain. Sci. 2017, 12, 1037-1053. [CrossRef]

28. Kumar, P.; Kumar, A.; Singh, C.K.; Saraswat, C.; Avtar, R.; Ramanathan, A.L.; Herath, S. Hydrogeochemical Evolution and Appraisal of Groundwater Quality in Panna District, Central India. Expo. Health 2016, 8, 19-30. [CrossRef]

29. Rahman, M.M.; Hagare, D.; Maheshwari, B. Framework to assess sources controlling soil salinity resulting from irrigation using recycled water: An application of Bayesian Belief Network. J. Clean. Prod. 2014, 105, 406-419. [CrossRef]

30. Hall, J.W.; Borgomeo, E. Risk-based principles for defining and managing water security risk-based principles for defining and managing water security. Philos. Trans. R. Soc. A 2013, 371, 20120407. [CrossRef] [PubMed]

31. Jensen, O.; Wu, H. Urban water security indicators: Development and pilot. Environ. Sci. Policy 2018, 83, 33-45. [CrossRef]

32. Dunn, G.; Bakker, K. Fresh Water-Related Indicators in Canada: An Inventory and Analysis. Can. Water Resour. J. 2011, 36, 135-148. [CrossRef]

33. Wiek, A.; Larson, K.L. Water, people, and sustainability-A systems framework for analyzing and assessing water gover-nance regimes. Water Resour Manag. 2012, 26, 3153-3171. [CrossRef]

34. Van-Rijswick, M.; Edelenbos, J.; Hellegers, P.; Kok, M.; Kuks, S. Ten building blocks for sustainable water governance: An integrated method to assess the governance of water. Water Int. 2014, 39, 725-742. [CrossRef]

35. Saraswat, C.; Kumar, P. Climate justice in lieu of climate change: A sustainable approach to respond to the climate change injustice and an awakening of the environmental movement. Energy Ecol. Environ. 2016, 1, 67-74. [CrossRef]

36. Cobbinah, P.B.; Okyere, D.K.; Gaisie, E. Population growth and water supply: The future of Ghanaian cities. In Megacities and Rapid Urbanization: Breakthroughs in Research and Practice; IGI Global: Pasadena, CA, USA, 2020; pp. $96-117$.

37. Ministry of Environment. Creation of a Regional Circular and Ecological Sphere (RCES) to Address Local Challenges. 2018. Available online: https://www.env.go.jp/policy/kihon_keikaku/plan/plan_5 (accessed on 20 August 2020). 
38. Kumar, P.; Johnson, B.A.; Dasgupta, R.; Avtar, R.; Chakraborty, S.; Masayuki, K.; Macandog, D. Participatory approach for enhancing robust water resource management: Case study of Santa Rosa sub-watershed near Laguna Lake, Philippines. Water 2020, 12, 1172. [CrossRef]

39. Rushing, M.; Primack, R.; Bonney, R. The history of public participation in ecological research. Front. Ecol. Environ. 2012, 10, 285-290. [CrossRef]

40. Johnson, B.; Mader, A.; Dasgupta, R.; Kumar, P. Citizen science websites/apps for invasive species sightings: An analysis of 26 ongoing initiatives. Glob. Ecol. Conserv. 2019, 21, e00812. [CrossRef]

41. Goodchild, M.F. Citizens as sensors: The world of volunteered geography. GeoJournal 2007, 69, 211-221. [CrossRef]

42. Jonker, L. IWRM: What should we teach? A report on curriculum development at the University of the Western Cape, South Africa. Phys. Chem. Earth Parts A/B/C 2005, 30, 881-885. [CrossRef]

43. Radif, A.A. Integrated water resource management (IWRM): An approach to face the challenges of the next century and to avert future crises. Desalination 1999, 124, 145-153. [CrossRef]

44. Uhlendahl, T.; Salian, P.; Casarotto, C.; Doetsch, J. Good water governance and IWRM in Zambia: Challenges and chances. Water Policy 2011, 13, 845-862. [CrossRef]

45. Kurian, M. The water-energy-food nexus: Trade-offs, thresholds and transdisciplinary approaches to sustainable development. Environ. Sci. Policy 2017, 68, 97-106. [CrossRef]

46. Baldassarre, D.; Viglione, G.A.; Carr, G.; Kuil, L.; Yan, K.; Brandimarte, L.; Bloschl, G. Debates-Perspectives on socio-hydrology: Capturing feedbacks between physical and social processes. Water Resour. Res. 2015, 51, 4770-4781. [CrossRef]

47. Mo, L.; Qiang, F.; Singh, V.P.; Dong, L.; Tianxiao, L. Stochastic multi-objective modelling for optimization of water-food-energy nexus of irrigated agriculture. Adv. Water Resour. 2019, 127, 209-224.

48. Sivapalan, M.; Konar, M.; Srinivasan, V.; Chhatre, A.; Wutich, A.; Scott, C.A.; Wescoat, J.L.; Iturbe, I.R. Socio-hydrology: Use-inspired water sustainability science for the Anthropocene. Earths Future 2014, 2, 225-230. [CrossRef]

49. Palmer, P.I.; Smith, M.J. Earth systems: Model human adaptation to climate change. Nature 2014, 7515, 365-366. [CrossRef]

50. Jamero, M.L.; Onuki, M.; Esteban, M.; Billones-Sensano, X.K.; Tan, N.; Nellas, A.; Takagi, H.; Thao, N.D.; Valenzuela, V.P. Small-island communities in the Philippines prefer local measures to relocation in response to sea-level rise. Nat. Clim. Chang. 2017, 7, 581-586. [CrossRef]

51. Tian, Y.; Hu, H.; Zhang, J. Solutions to water resource scarcity: Water reclamation and reuse. Environ. Sci. Pollut. Res. 2017, 24, 5095-5097. [CrossRef] [PubMed]

52. Lin, X.; Xu, J.; Keller, A.A.; He, L.; Gu, Y.; Zheng, W.; Sun, D.; Lu, Z.; Huang, J.; Huang, X.; et al. Occurrence and risk assessment of emerging contaminants in a water reclamation and ecological reuse project. Sci. Total Environ. 2020, 744, 140977. [CrossRef]

53. Voulvoulis, N. The potential of water reuse as a management option for water security under the ecosystem services approach. Desalination Water Treat. 2015, 53, 3263-3271. [CrossRef]

54. Bagdi, G.L.; Mishra, P.K.; Kurothe, R.S.; Arya, S.L.; Patil, S.L.; Singh, A.K.; Bihari, B.; Prakash, O.; Kumar, A.; Sundarambal, P. Post-adaptation behaviour of farmers towards soil and water conservation technologies of watershed management in India. Inter. Soil \& Water Cons. Res. 2015, 3, 161-169.

55. O'Brien, A.; Townsend, K.; Hale, R.; Sharley, D.; Pettigrove, V. How is ecosystem health defined and measured? A critical review of freshwater and estuarine studies. Ecol. Ind. 2016, 8, 722-729. [CrossRef]

56. Chakraborty, A.; Chakraborty, S. Rivers as Socioecological Landscapes. In Rivers and Society: Landscapes Governance and Livelihoods; Earthscan Studies in Water Resource Management; Cooper, M., Chakraborty, A., Chakraborty, S., Eds.; Earthscan; Routledge: London, UK, 2017; Chapter 2; pp. 9-26.

57. Wohl, E. Connectivity in rivers. Prog. Phys. Geogr. Earth Environ. 2017, 41. [CrossRef]

58. Gunderson, L.H.; Holling, C.S.; Light, S. Barriers and Bridges to Renewal of Ecosystems and Institutions; Columbia University Press: New York, NY, USA, 1995.

59. Van-Rees, C.B.; Cañizares, J.R.; Garcia, G.M.; Reed, J.M. Ecological stakeholder analogs as intermediaries between freshwater biodiversity conservation and sustainable water management. Environ. Pol. Gov. 2019, 29, 303-312. [CrossRef]

60. Vollmer, D.; Shaad, K.; Souter, N.J.; Farrell, T.; Dudgeon, D.; Sullivan, C.A.; Fauconnier, I.; MacDonald, G.M.; McCartney, M.P.; Power, A.G.; et al. Integrating the social, hydrological and ecological dimensions of freshwater health: The Freshwater Health Index. Sci. Total Environ. 2018, 627, 304-313. [CrossRef]

61. Lee, K.H.; Schuett, M.A. Exploring spatial variations in the relationships between residents' recreation demand and associated factors: A case study in Texas. Appl. Geogr. 2014, 53, 213-222. [CrossRef]

62. Parsons, M.; Thoms, M.; Capon, T.; Capon, S.; Reid, M. Resilience and Thresholds in River Ecosystems; National Water Commission; Waterlines: Canberra, Australia, 2009.

63. Head, B.W. Managing urban water crises: Adaptive policy responses to drought and flood in Southeast Queensland, Australia. Ecol. Soc. 2014, 19, 33. [CrossRef]

64. Endo, I.; Didham, R.J. Participatory Watershed Land-Use Management Approach: Interfacing Science, Policy and Participation for Effective Decision Making; IGES: Hayama, Japan, 2016; Available online: https: / / www.iges.or.jp/en/pub / participatory-watershed-landuse-management-0/en (accessed on 2 September 2020).

65. Lindsay, J.; Rogers, B.C.; Church, E.; Gunn, A.; Hammer, K.; Dean, A.J.; Fielding, K. The Role of Community Champions in Long-Term Sustainable Urban Water Planning. Water 2019, 11, 476. [CrossRef] 
66. Godschalk, D.R.; Brody, S.; Burby, R. Public Participation in Natural Hazard Mitigation Policy Formation: Challenges for Comprehensive Planning. J. Environ. Plan. Manag. 2010, 46, 733-754. [CrossRef]

67. Biggs, E.M.; Bruce, E.; Boruff, B.; Duncan, J.M.A.; Horsley, J.; Pauli, N.; McNeil, K.; Neef, A.; Ogtrop, F.V.; Curnow, J.; et al. Sustainable development and the water-energy-food nexus: A perspective on livelihoods. Environ. Sci. Policy 2015, 54, 389-397. [CrossRef]

68. Bazilian, M.; Rogner, H.; Hoells, M.; Hermann, S.; Arent, D.; Gielen, D.; Steduto, P.; Mueller, A.; Komor, P.; Tol, R.S.J.; et al. Considering the energy, water and food nexus: Towards an integrated modelling approach. Energy Policy 2011, 39, 7896-7906. [CrossRef]

69. Vörösmarty, C.J.; Osuna, V.R.; Cak, A.; Bhaduri, A.; Bunn, S.E.; Corsi, F.; Gastelumendi, J.; Green, P.; Harrison, I.; Lawford, R.; et al. Ecosystem-based water security and the sustainable development goals. Ecohydrol. Hydrobiol. 2018. [CrossRef]

70. UN-United Nations. Sustainable Development Goal 6 Synthesis Report 2018 on Water and Sanitation; United Nations Publishers: New York, NY, USA, 2018.

71. Padowski, J.C.; Gorelick, S.M. Global analysis of urban surface water supply vulnerability. Environ. Res. Lett. 2014, 9, 104004. [CrossRef] 